\title{
Effects of anoestrus and bromocryptine treatment on the expression of prolactin and LH receptors in the rabbit ovary during lactation
}

\author{
A. Y. Kermabon ${ }^{1}$, L. Belair ${ }^{1}$, M. Theau-Clément ${ }^{2}$, R. Salesse ${ }^{1}$ and \\ J. Djiane ${ }^{1}$ \\ ${ }^{1}$ Unité Endocrinologie Moléculaire et Unité d'Ingénerie des Protéines, Laboratoire de Biologie Cellulaire et \\ Moléculaire, Institut National de la Recherche Agronomique, 78352 Jouy en Josas Cedex, France; and \\ ${ }^{2}$ Station d'Amélioration Génétique des Animaux, BP 27, Institut National de la Recherche Agronomique, \\ 31326 Castanet Tolosan Cedex, France
}

\begin{abstract}
The aim of the present study was to correlate the number of prolactin and $\mathrm{LH}$ receptors in the ovary with the changes in sexual behaviour that occur within a few days following parturition in rabbits. Multiparous New Zealand white rabbits at days 0, 3 and 10 of lactation were tested for their receptivity upon presentation to a male. Rabbits were classed as either receptive or nonreceptive at each stage of lactation; half of the animals in each class were treated with bromocryptine to examine the effects of prolactin deprivation. Ovarian receptors for $\mathrm{LH}$ and prolactin, as well as the concentration of their corresponding mRNA, were measured at each stage of lactation in every group. Results indicate that receptive behaviour is correlated with significantly more follicles on the rabbit ovary (diameter $>1 \mathrm{~mm} ; P<0.05)$ and an increase in the concentration of LH receptor mRNA $(P<0.001)$ and prolactin receptors $(P<0.05)$. In addition, on day 4 of lactation, there were significantly fewer follicles in nonreceptive rabbits $(P<0.05)$. LH receptor content remained constant on days 1 and 4 of lactation but increased on day $11(P<0.05)$. Bromocryptine treatment had no effect on the number of follicles or on the amount of LH receptor mRNA in does, but it significantly increased LH receptors $(P<0.01)$, and the concentration of prolactin receptor mRNA $(P<0.001)$, particularly on day 11 of lactation $(P<0.05)$, and prolactin receptor content $(P<0.001)$. Receptive rabbit ovaries therefore display more follicles that can respond to an LH surge via newly transcribed LH receptors than do nonreceptive. Bromocryptine treatment seems to relieve some repressive activity exerted by prolactin on the number of LH receptors in the rabbit ovary.
\end{abstract}

\section{Introduction}

Prolactin is involved in a number of physiological processes, including milk production, growth, osmoregulation and reproduction in a wide range of species of vertebrates (Nicoll, 1980; Kelly et al., 1991). In mammals, the high concentrations of prolactin observed during lactation coincide with a reduction in gonadotrophin secretion. The pulsatile secretion of $\mathrm{LH}$ that is essential for ovulation in females (Erickson, 1983) is especially diminished (McNeilly, 1987). This restriction results in the suppression of ovarian activity, and seems to be correlated with the intensity of suckling in women (Howie and McNeilly, 1982). In sows, pituitary concentrations of $\mathrm{LH}$ are also lower during lactation (Crighton and Lamming, 1969), suggesting that both synthesis and release of LH are inhibited by suckling.

The mammary gland is the classical target of prolactin action and contains a high concentration of receptors (Djiane et al., 1977; Durand and Djiane, 1977; Jahn et al., 1991).

Received 11 February 1994
Prolactin receptor mRNA has been detected in rabbit ovaries (Dusanter-Fourt et al., 1991). Prolactin receptors could play a role in folliculogenesis and in ovulation, as demonstrated in rats (Richards and Williams, 1976; Veldhuis and Hammond, 1980; McNeilly, 1987). The role of prolactin in the ovary varies according to species as well as to the type of ovarian cell studied. This lactogenic hormone has been implicated in various ovarian functions including the stimulation of progesterone secretion in human granulosa cells at physiological concentrations, although higher doses are inhibitory (McNatty et al., 1974). Inhibitory effects have been reported on oestradiol production in rat granulosa cells (Wang et al., 1980), androgen secretion by thecal cells (Magoffin and Erickson, 1982), aromatase activity (Tsai-Morris et al., 1983), oocyte maturation (Channing and Evans, 1982) and hCG-induced ovulation in rabbits (Hamada et al., 1980; Yoshimura et al., 1992).

During lactation, many farm animals display a period of sexual inactivity described as anoestrus (Peters and Lamming, 1990). In contrast to many farm animals, the rabbit does not show regular oestrous cycles (Moret, 1980) and ovulation is 
induced by mating. Generally, does tend to be sexually receptive to males up to $48 \mathrm{~h}$ post partum (Beyer and Rivaud, 1969; Stoufflet and Caillol, 1988), even though the number of corpora lutea remains significantly low (Lamb et al., 1988). At 3-5 days after parturition, the majority of does are nonreceptive (Theau-Clément and Roustan, 1992). Conversely, females become moderately receptive to males 10-12 days post partum. There appears to be a partial antagonism between specific stages of lactation and reproductive function (Theau-Clement and Roustan, 1992). There is an increasing interest in artificial insemination for breeding of rabbits. Since the doe can have a concurrent gestation and lactation, an intensive rhythm of reproduction is often adopted by breeders to increase the efficiency in rabbit reproduction. This study was undertaken in an attempt to describe the physiological mechanisms limiting the ovulation in does that are concurrently lactating and are nonreceptive.

The aim of this study was to correlate behavioural changes during lactation with the number of antral follicles present on rabbit ovaries and the expression of $\mathrm{LH}$ and prolactin receptors at the mRNA and protein levels. The fluctuation of these receptors and in their mRNA concentrations could provide insight into the ability of the ovary to respond to pituitary hormones at various physiological stages. Such an analysis might help to determine whether the inhibition of prolactin secretion could improve reproductive performances in animals displaying anoestrous behaviour.

In this study, multiparous New Zealand white rabbits were taken at different stages of lactation (days 0, 3 and 10 after parturition) and were tested for their receptivity upon presentation to a male. Rabbits were classified into two groups: receptive $(R+)$ or nonreceptive $(R-)$. Half of the animals in each group were treated with bromocryptine (CB-154), a dopamine agonist and inhibitor of prolactin secretion, to examine the effects of prolactin deprivation on the rabbit ovary. After $36 \mathrm{~h}$, the number of follicles and the number of ovarian receptors for $\mathrm{LH}$ and prolactin, as well as the amount of their cognate mRNA, were determined in receptive, nonreceptive, control and bromocryptine-treated animals at each stage of lactation.

\section{Materials and Methods}

\section{Animals}

Female, lactating, multiparous New Zealand white rabbits ( $n=120 ; 3.5-4.5 \mathrm{~kg}$; all had given birth to at least six litters) from INRA line A9077 were housed individually in standard cages under a controlled photoperiod ( $16 \mathrm{~h}$ light: $8 \mathrm{~h}$ dark) and had unrestricted access to food and water. The does were tested for their sexual receptivity upon presentation to a male on day 0,3 or 10 of lactation. A doe was considered to be sexually receptive when the behaviour she displayed in the presence of a buck showed that she was willing to mate by adopting a lordosis position (Theau-Clement and Roustan, 1992). Among a group of 40 animals for each stage of lactation, 10 rabbits were selected in each group as receptive $(\mathrm{R}+)$ and nonreceptive $(\mathrm{R}-)$. Half of the animals in each group $(n=4-6)$ were selected as control animals (T - ) and the other half were injected $(\mathrm{T}+$ ) with $2 \mathrm{mg}$ bromocryptine (CB-154 or 2-bromo- $\alpha$-ergocryptine-methane-sulfonate, kindly supplied by Sandoz Ltd, Basel) to lower circulating prolactin concentrations. The treated animals received a dose of $2 \mathrm{mg}$ CB-154 36, 24 and $12 \mathrm{~h}$ before they were killed. Does were killed by cervical dislocation approximately $2-5 \mathrm{~h}$ after the last suckling, and a blood sample and ovaries were collected. Individual follicles were counted and their outside diameter was recorded. The ovaries were snap-frozen in liquid nitrogen and stored at $-80^{\circ} \mathrm{C}$ until further use. Blood samples collected from every animal were centrifuged $(3000 \mathrm{~g}, 10 \mathrm{~min})$, and plasma were stored at $-20^{\circ} \mathrm{C}$. The concentration of rabbit prolactin was assayed in each sample to ensure that the bromocryptine treatment had suppressed prolactin secretion. This verification was done using the immunoreagents (rabbit prolactin radioimmunoassay) supplied by A. F. Parlow (Pituitary Hormones and Antisera Center, Torrance, CA), and the assay was performed as described by Muccioli et al., 1983.

\section{Measurement of prolactin and $\mathrm{LH}$ binding sites}

Ovarian rabbit membranes (microsomes) were prepared individually as described by Djiane et al., 1977. This method of preparation of microsomes allows the determination of unoccupied receptor sites. Briefly, one ovary from each rabbit was homogenized using an Ultraturrax homogenizer at $4^{\circ} \mathrm{C}$ in $3 \mathrm{ml}$ homogenization buffer [10 mmol Tris- $\mathrm{HCl} 1^{-1}$ (pH 7.4), $3.8 \mathrm{mmol} \mathrm{NaCl} 1^{-1}, 3 \mathrm{mmol} \mathrm{KCl} \mathrm{l}^{-1}, 1 \mathrm{mmol}$ phenyl-methyl sulfonyl fluoride (PMSF) $\mathrm{I}^{-1}, 1 \mathrm{mmol}$ benzamidine $\mathrm{l}^{-1}$ and $0.04 \% \mathrm{NaN}_{3}$ ]. The homogenate was centrifuged for $15 \mathrm{~min}$ at $500 \mathrm{~g}$ at $4^{\circ} \mathrm{C}$, and its supernatant was centrifuged for $90 \mathrm{~min}$ at $100000 \mathrm{~g}$ at the same temperature. The resulting pellet was resuspended in the homogenization buffer and a fraction of the membrane preparation was assayed for protein content by the method of Lowry et al. (1951). The microsomes were stored at $-20^{\circ} \mathrm{C}$ until use.

Purified hCG (a generous gift from R. Canfield, NIH, Bethesda, MD) was labelled with ${ }^{125} \mathrm{I}$ using lodogen as a catalyst (Genty et al., 1987). Ovine (o) prolactin (NIDDK

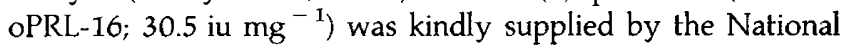
Hormone and Pituitary Program (NIH, Bethesda, MD) and was iodinated using chloramine $\mathrm{T}$ by the method of Greenwood et al. (1963). The labelled hormones were purified on a PD-10 Sephadex G-25 Column (Pharmacia, St Quentin en Yvelines); the specific activity of the resulting tracer was $2200 \mathrm{Ci}$ $\mathrm{mmol}^{-1}$ for o-prolactin and $1500 \mathrm{Ci} \mathrm{mmol}^{-1}$ for hCG.

Specific binding of ${ }^{125}$ I-labelled o-prolactin and ${ }^{125}$ I-labelled hCG to membranes prepared from each ovary was determined at three duplicate dilutions (100, 200 and $400 \mu \mathrm{g}$ of protein) to ascertain the linear binding of each tracer. Total binding was determined in the presence of $40-100 \mathrm{nmol}{ }^{125}$ I-labelled o-prolactin or ${ }^{125} \mathrm{I}$-labelled hCG, and nonspecific binding in the presence of a large excess of unlabelled o-prolactin or hCG (Chorulon, Intervet, Angers). After incubation for $16 \mathrm{~h}$ at $20^{\circ} \mathrm{C}$, the hCG incubation was stopped with a buffer containing $3 \mathrm{ml}$ ice-cold $10 \mathrm{mmol}$ Tris- $\mathrm{HCl}{ }^{-1}(\mathrm{pH} \mathrm{7.4)}$, while the o-prolactin incubation was stopped with a buffer containing $3 \mathrm{ml} 25 \mathrm{mmol}$ Tris- $\mathrm{HCl} \mathrm{l}^{-1}$ (pH 7.4), $10 \mathrm{mmol} \mathrm{MgCl}_{2} \mathrm{l}^{-1}$ and 0.1\% BSA. Bound and free hormones were separated by centrifugation at 
$3500 \mathrm{~g}$ at $4^{\circ} \mathrm{C}$ for $20 \mathrm{~min}$. The supernatant was aspirated and the radioactivity of the membrane pellet was determined using a LKB gamma counter. Specific binding was calculated and divided by the total radioactivity to yield the percentage of specific binding.

\section{RNA preparation}

Total RNA was isolated from the second ovary of each animal according to the procedure of Chomczynski and Sacchi (1987) as modified by Puissant and Houdebine (1990). One ovary from each animal was homogenized individually in three volumes $(\mathrm{w} / \mathrm{v})$ of $4.2 \mathrm{~mol}$ guanidinium thiocyanate $\mathrm{I}^{-1}$ (Fluka; Biochemicka, Buchs) solution containing $25 \mathrm{mmol}$ sodium citrate $\mathrm{l}^{-1}, 0.5 \% \quad \mathrm{w} / \mathrm{v} \quad n$-lauroyl-sarcosine and $0.1 \mathrm{~mol}$ $\beta$-mercaptoethanol $\mathrm{l}^{-1}$. To this mixture, 0.1 volume of $2 \mathrm{~mol}$ sodium acetate $1^{-1}(\mathrm{pH} 4)$ was added and a first extraction with one volume phenol (water-saturated) and 0.2 volume chloroform (chloroform : iso-amyl alcohol, 49:1) was performed. The mixture was placed in ice for $15 \mathrm{~min}$, centrifuged for $30 \mathrm{~min}$ at $3000 \mathrm{~g}$, and the aqueous phase was then precipitated by adding one volume of isopropanol overnight at $-20^{\circ} \mathrm{C}$. The RNA pellet was recovered by centrifugation $\left(30 \mathrm{~min}, 3000 \mathrm{~g}, 4^{\circ} \mathrm{C}\right.$ ), rinsed with $70 \%$ ethanol, and dissolved in sterile water. RNAs were precipitated by adding six volumes of $4 \mathrm{~mol} \mathrm{LiCl} \mathrm{I}^{-1}$ and were then kept at $4^{\circ} \mathrm{C}$. After $4 \mathrm{~h}$, the RNA pellet was recovered by centrifugation $\left(12000 \mathrm{~g}, 30 \mathrm{~min}, 4^{\circ} \mathrm{C}\right)$, rinsed with $70 \%$ ethanol and the dried pellet was dissolved in $1 \mathrm{ml}$ of $10 \mathrm{mmol}$ Tris- $\mathrm{HCl} 1^{-1}$ buffer ( $\mathrm{pH} \mathrm{7.5)}$ containing $1 \mathrm{mmol}$ EDTA $\mathrm{I}^{-1}$ and $0.5 \% \mathrm{w} / \mathrm{v}$ SDS solution. The pellet was then precipitated in ethanol $(100 \%)$ at $-20^{\circ} \mathrm{C}$ in the presence of 0.2 mol sodium acetate $1^{-1}(\mathrm{pH} 4)$. The RNA pellet was recovered by centrifugation $\left(12000 \mathrm{~g}, 30 \mathrm{~min}, 4^{\circ} \mathrm{C}\right)$, and was dissolved in $500 \mu \mathrm{l}$ of a solution containing $10 \mathrm{mmol}$ Tris $-\mathrm{HCl}$ $\mathrm{l}^{-1}$ (pH 7.5), $0.12 \mathrm{~mol} \mathrm{NaCl}^{-1}, 1 \mathrm{mmol}^{-1} \mathrm{EDT} \mathrm{I}^{-1}$ and $0.5 \%$ SDS. RNA was quantified by optical density measurements at $260 \mathrm{~nm}$ and distributed into aliquots of 20 and $40 \mu \mathrm{g}$. RNA samples were kept in an ethanol-precipitated form at $-20^{\circ} \mathrm{C}$.

\section{Slot blot analysis}

For slot blot analysis, RNA from each animal was individually analysed. Briefly, $40 \mu \mathrm{g}$ of ethanol-precipitated RNAs were centrifuged ( $30 \mathrm{~min}, 12000 \mathrm{~g}, 4^{\circ} \mathrm{C}$ ), washed with $70 \%$ ethanol, dried and dissolved in $100 \mu \mathrm{l} 2 \times \mathrm{SSC}(1 \times \mathrm{SSC}=0.15 \mathrm{~mol}$ $\mathrm{NaCl} l^{-1}, 0.015 \mathrm{~mol}$ sodium citrate $\mathrm{l}^{-1}$ ) containing $7 \% \mathrm{v} / \mathrm{v}$ formaldehyde. RNA samples were denatured and taken to a volume of $1 \mathrm{ml}$ with $20 \times \mathrm{SSC}$. Then 2,4 and $8 \mu \mathrm{g}$ of each RNA preparation was deposited on to a Hybond C-extra nitrocellulose using a MINIFOLD II apparatus (Schleicher and Schuell, Ecquevilly). Filters were baked for $2 \mathrm{~h}$ at $80^{\circ} \mathrm{C}$ and then prehybridized in a solution consisting of $50 \%(\mathrm{v} / \mathrm{v})$ deionized formamide, $5 \times$ Denhardt's solution [ $1 \times$ Denhardt $=0.002 \%$ $(\mathrm{w} / \mathrm{v})$ each of BSA, Ficoll and polyvinylpyrrolidone], $5 \times \mathrm{SSPE}$ $\left(1 \times \mathrm{SSPE}=1.115 \mathrm{~mol} \mathrm{NaCl} \mathrm{l}^{-1}, 0.01 \mathrm{~mol} \mathrm{NaH}_{2} \mathrm{PO}_{4} \mathrm{l}^{-1}\right.$ and $1 \mathrm{mmol} \mathrm{EDTA} \mathrm{I}^{-1}$ ), $250 \mu \mathrm{g}$ denatured salmon sperm DNA ml and $0.1 \% \mathrm{SDS}$ for $3 \mathrm{~h}$ at $42^{\circ} \mathrm{C}$. The filters were then hybridized overnight in the same conditions with radiolabelled cDNA probes (see below) in the following order: prolactin receptor, LH receptor, and $\beta$-actin. The filters were autoradiographed and stripped of any remaining probe before hybridization with the next probe.

All cDNA fragments were purified free of vector DNA by suitable endonuclease (purchased from Boehringer Mannheim, Meylan) digestion and agarose gel electrophoresis. A $0.6 \mathrm{~kb}$ fragment (nt 344-944) encoding the rabbit prolactin receptor cDNA (Edery et al., 1989) and a cDNA encoding the full-length $(2.2 \mathrm{~kb})$ porcine LH receptor (Loosfelt et al., 1989) and a mouse $\beta$-actin cDNA (Alonso et al, 1986) were used. Each probe was labelled by random priming with the Amersham Multiprime kit (Amersham, Les Ulis) using $\left[\alpha^{32} \mathrm{P}\right] \mathrm{dCTP}$ $\left(3000 \mathrm{Ci} \mathrm{mmol}{ }^{-1}\right)$ for $3 \mathrm{~h}$ at room temperature to specific activities of $0.5-1 \times 10^{9}$ c.p.m. $\mu g^{-1}$. Unincorporated nucleotide triphosphates were eliminated using a Sephadex G-50 Nick Column (Pharmacia, St Quentin en Yvelines).

At the end of the hybridization period, the blots were washed once in a solution containing $0.1 \times$ SSC, $0.1 \%$ SDS and $1 \mathrm{mmol}$ EDTA $~^{-1}$ for $10 \mathrm{~min}$ at room temperature, followed by two washes in the same solution for $30 \mathrm{~min}$ at $60^{\circ} \mathrm{C}$. Filters were exposed to Kodak X-Omat S films at $-70^{\circ} \mathrm{C}$ for $12 \mathrm{~h}$ with two intensifying screens. Autoradiograms were analysed by densitometric scanning (using a Biocom Image Analysis System, with a Lecphor program from Touzart \& Matignon, Vitry). Hybridization intensities (expressed in arbitrary units) were calculated as signal (dot optical density) : noise (optical density of film background) ratios, and normalized to the signal of the actin probe. Control (negative) spleen samples were used to determine the threshold of positive hybridization.

\section{Statistical analyses}

An analysis of variance was performed on each set of experimental data using the ' $S$ ' package edited by J. M. Chambers and T. J. Hastie (AT\&T Bell Laboratories, Wadsworth \& Brooks/ Cole Advanced Books \& Software, Pacific Grove, CA). Subsequent comparisons between means were performed using the Newman-Keuls test. A $P$ value $\leqslant 0.05$ was considered significant.

\section{Results}

\section{Suppression of prolactin secretion by bromocryptine}

Mean circulating prolactin concentrations were similar in receptive does $\left(203 \pm 64 \mathrm{ng} \mathrm{ml}^{-1}\right)$ and nonreceptive does $\left(207 \pm 36 \mathrm{ng} \mathrm{ml}^{-1}\right)$. However, does treated with bromocryptine had reduced prolactin concentrations, either when exhibiting oestrous $\left(18.0 \pm 12.3 \mathrm{ng} \mathrm{ml} \mathrm{m}^{-1}\right)$ or anoestrous $\left(5.9 \pm 1.6 \mathrm{ng} \mathrm{ml}^{-1}\right)$ behaviour. Bromocryptine was therefore effective in suppressing prolactin secretion.

\section{Number of follicles present on the surface of the rabbit ovary}

On days 1,4 and 11 of lactation, receptive animals had a higher mean number of follicles compared with nonreceptive animals $(9.81 \pm 0.35$ versus $8.32 \pm 0.56 ; P<0.05)$. In addition, significantly fewer follicles were present in nonreceptive ( $\mathrm{T}-$ and $\mathrm{T}+$ ) animals on day 4 than at the other two stages of lactation $[6.80 \pm 0.83$ versus $8.50 \pm 0.97$ (day 1 ) and 


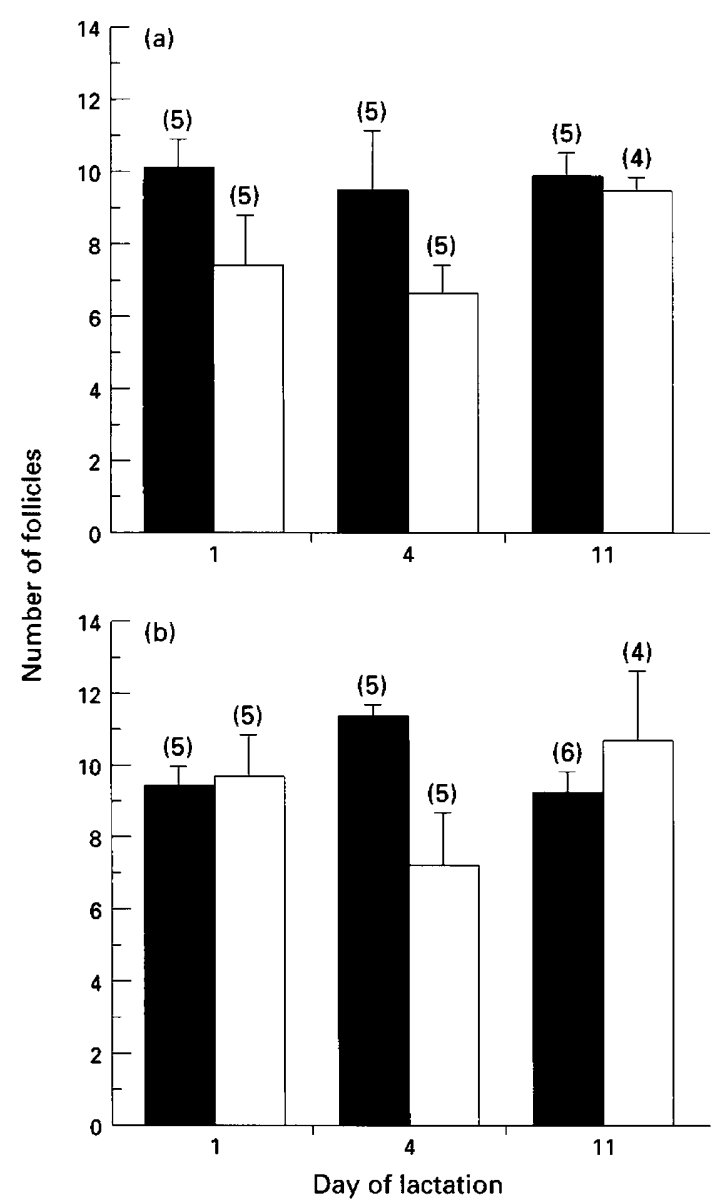

Fig. 1. Number of follicles (diameter $>1 \mathrm{~mm}$ ) present on the rabbit ovary at various stages of lactation. Individual follicles were measured under an ocular micrometer and their outside diameters recorded on both ovaries on all the animals. Mean values ( \pm SEM) were calculated for each category to facilitate visualization of the results, and the number per group is indicated in parentheses. (a) Control does. (b) Bromocryptine-treated does. ( $\square$ ) Receptive females; ( $\square$ ) nonreceptive females. Receptive behaviour is correlated with a significantly higher mean number of follicles compared with nonreceptive does $(P<0.05)$. At day 4 of lactation, the mean number of follicles is significantly lower in nonreceptive rabbits $(P<0.05)$ than in receptive rabbits.

$10.4 \pm 0.93$ (day 11); $P<0.05$; Fig. 1]. However, neither the day of lactation $[9.10 \pm 0.55$ (day 1); $8.60 \pm 0.70$ (day 4); $9.63 \pm 0.45$ (day 11)] nor bromocryptine treatment $[8.79 \pm 0.47$ $(\mathrm{T}-)$ versus $9.40 \pm 0.47(\mathrm{~T}+)]$ had significant effects on the mean number of preovulatory follicles. The effect of oestrous behaviour $(\mathrm{R}+)$ therefore overrides the effects of lactational stage and bromocryptine treatment on the number of follicles in the rabbit ovary.

\section{Slot blot experiments}

Figure 2 shows the results obtained from a typical dot blot experiment for each probe on day 11 of lactation (results from days $I$ and 4 are not shown). The analysis of the mRNA quantification for the LH receptor is shown in Fig. 3; and that for prolactin receptor mRNA is shown in Fig. 4.

\section{Expression of the $\mathrm{LH}$ receptor}

Receptive animals exhibited higher concentrations of LH-receptor mRNA compared with nonreceptive animals ( $1.11 \pm 0.1$ versus $0.43 \pm 0.05 ; P<0.001 ;$ Fig. 3 ). Neither the day of lactation $[0.78 \pm 0.13$ (day 1 ); $0.63 \pm 0.12$ (day 4); $0.99 \pm 0.13$ (day 11)] nor the bromocryptine treatment $[0.86 \pm 0.12(\mathrm{~T}-)$ versus $0.75 \pm 0.09(\mathrm{~T}+)]$ affected the accumulation of $\mathrm{LH}$ receptor mRNA to a significant degree. Therefore, as in the case of the mean number of follicles, receptive behaviour overrides any other parameter examined for its effect on the amount of LH receptor mRNA throughout lactation.

The percentage of specific binding of $\left[{ }^{125} \mathrm{I}\right] \mathrm{hCG}$ to $\mathrm{LH}$ receptors during the different stages of lactation is shown (Fig. 5). The day of lactation and bromocryptine treatment had a highly significant influence on LH receptor content. On day 1 and 4 of lactation, the concentration of LH receptors remained constant but significantly increased on day 11 $(0.69 \pm 0.11$ and $0.89 \pm 0.16$ versus $1.60 \pm 0.24 ; P<0.05)$. In bromocryptine-treated rabbits, the concentration of LH receptors was higher than in untreated animals $(1.33 \pm 0.18$ versus $0.79 \pm 0.11 ; P<0.01)$ indicating that prolactin may exert some inhibition on LH receptor expression. However, the maximal specific binding of hCG was approximately $2 \%$, even at the highest homogenate concentrations, indicating that the $\mathrm{LH}$ receptor is present at low concentrations in the rabbit ovary.

\section{Expression of the prolactin receptor}

Receptive behaviour was not significantly correlated with the expression of prolactin receptor mRNA ( $1.38 \pm 0.13$ versus $1.24 \pm 0.16$, Fig. 4). However, the day of lactation $[0.95 \pm 0.10$ (day 1); $0.99 \pm 0.06$ (day 4); $2.01 \pm 0.20$ (day I1); $P<0.001$ ] was associated with bromocryptine treatment $[1.04 \pm 0.09$ $(\mathrm{T}-)$ versus $1.57 \pm 0.16(\mathrm{~T}+) ; P<0.001]$. Moreover, the two variables, day and treatment, had a significant influence on prolactin receptor mRNA $(P<0.01)$. Bromocryptine-treated animals showed a significantly higher concentration of prolactin receptor mRNA on day 11 of lactation than at other stages $[2.54 \pm 0.27$ versus $0.83 \pm 0.06$ (day 4 ) and $1.43 \pm 0.16$ (day 1); $P<0.05$ ).

The day of lactation had no significant effect on the concentration of prolactin receptors in the rabbit ovary (Fig. 6). In contrast, oestrous behaviour was correlated with a significant increase in binding of ${ }^{125} \mathrm{I}$-labelled prolactin $(6.25 \pm 0.65 \%$ versus $5.18 \pm 0.44 \% ; P<0.05$ ). In addition, as in the case of prolactin receptor mRNA, increased numbers of o-prolactin binding sites were also observed for bromocryptine-treated animals compared with control animals $(7.67 \pm 0.49 \%$ versus $3.69 \pm 0.3 \% ; P<0.001$ ). These results indicate that an increased concentration of ovarian prolactin receptors occurs in the bromocryptine-treated does as well as in does showing oestrous behaviour. 
(a)

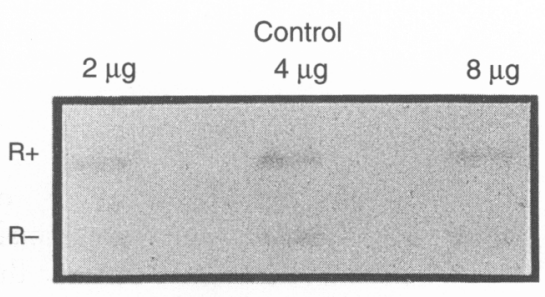

Treated

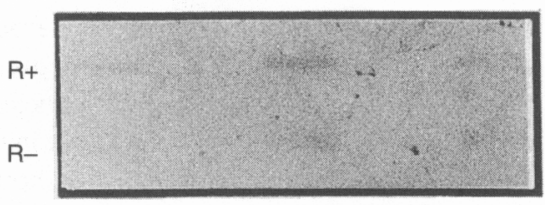

(b)

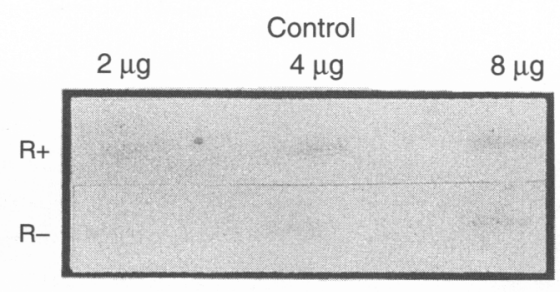

Treated

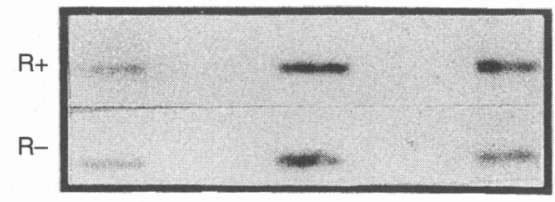

(c)

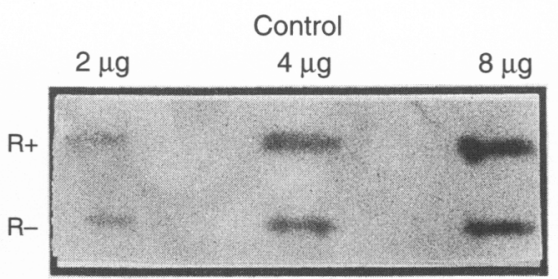

Treated

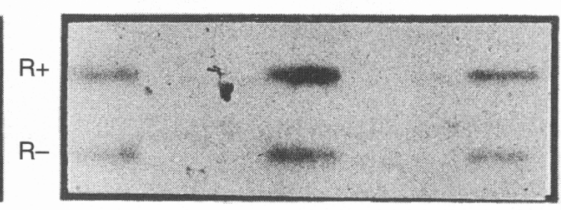

Control RNA
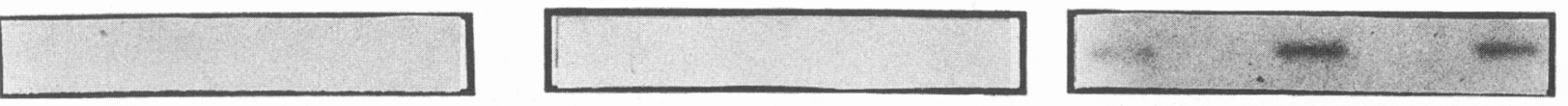

Fig. 2. Expression of mRNA encoding ovarian prolactin receptors and LH receptors in the rabbit on day 11 of lactation. Total RNA was isolated from rabbit ovaries at different stages of lactation and quantified on slot blots and expressed in arbitrary units. The figure shows the results from day 11 of lactation (results from days 1 and 4 are not shown). Lanes 1,2 and 3 were injected with 2, 4 and $8 \mu \mathrm{g}$ total RNA, respectively. The expression of specific mRNAs was analysed using the following cDNA probes: (a) porcine $\mathrm{LH}$ receptor (2.2 Kb); (b) rabbit prolactin receptor (nt344-944); and (c) a mouse $\beta$-actin probe used as a control in the densitometric measurements. The amount of mRNA for the two receptors and actin were quantified on slot blots and expressed in arbitrary units. Hybridization intensities (expressed in arbitrary units) were calculated as a signal (dot optical density):noise (optical density of film background) ratio, and normalized to the signal of the actin probe. The control RNA used was spleen total RNA, which was used to determine the threshold of positive hybridization. $R+:$ receptive females; $\mathrm{R}-$ : nonreceptive females.

None of the interactions of the third order were significant at $P<0.05$. The number of follicles was significantly correlated with the day of lactation and receptivity $(P<0.05)$. In addition, a significant interaction between the day of lactation and treatment was observed for the prolactin receptor mRNA $(P<0.01)$

\section{Discussion}

The aim of this study was to correlate oestrous behaviour during lactation in does with ovarian parameters such as the number of follicles and the expression of $\mathrm{LH}$ and prolactin receptors. In addition, the effects of prolactin deprivation were examined in ovaries of lactating rabbits treated with bromocryptine.

Receptivity to males in does was found to be correlated with a higher number of follicles present on the surface of the rabbit ovary. At days 3-5 after parturition, most females studied were nonreceptive, which coincided with significantly fewer follicles on day 4 of lactation compared with the other stages in nonreceptive does. Oestrogens, mainly of ovarian origin, are known to play a positive role in the neural systems responsible for receptive behaviour in does (Beyer and McDonald, 1973). Since nonreceptive does have fewer preovulatory follicles than do receptive does, they consequently produce lower concentrations of circulating oestrogens (Stoufflet and Caillol, 988 ).
This depletion can in turn affect mating behaviour as well as folliculogenesis by decreasing circulating concentrations of gonadotrophins.

However, bromocryptine-treated animals do not have a higher number of follicles (at every stage), indicating that prolactin does not play a role in the quantity, but perhaps on the activity, of the follicles.

Does showing oestrous behaviour have a large number of follicles preparing to respond to a preovulatory surge of $\mathrm{LH}$ via newly transcribed receptors, as seen by the high concentration of LH receptor mRNA during this time. This result suggests that the factor(s) required for the appearance of $\mathrm{LH}$ receptor mRNA are present in receptive animals and absent or diminished in nonreceptive animals. The regulation of the LH receptor gene is complex and involves several factors. Goxe et al. (1992) demonstrated that the transcription of the LH receptor gene was stimulated by the presence of FSH, oestradiol and insulin in cultured porcine granulosa cells as soon as $24 \mathrm{~h}$ after stimulation. However, in their study as well as in our model, the increase in LH receptor RNA does not seem to yield a proportional increase in receptor content, indicating some post-transcriptional regulations.

As lactation progresses, the concentration of $\mathrm{LH}$ receptors increases significantly as seen at day 11 of lactation. Bromocryptine treatment does not affect the amount of $\mathrm{LH}$ receptor mRNA accumulation, but significantly increases the number of LH receptors. The circulating concentration of prolactin was 


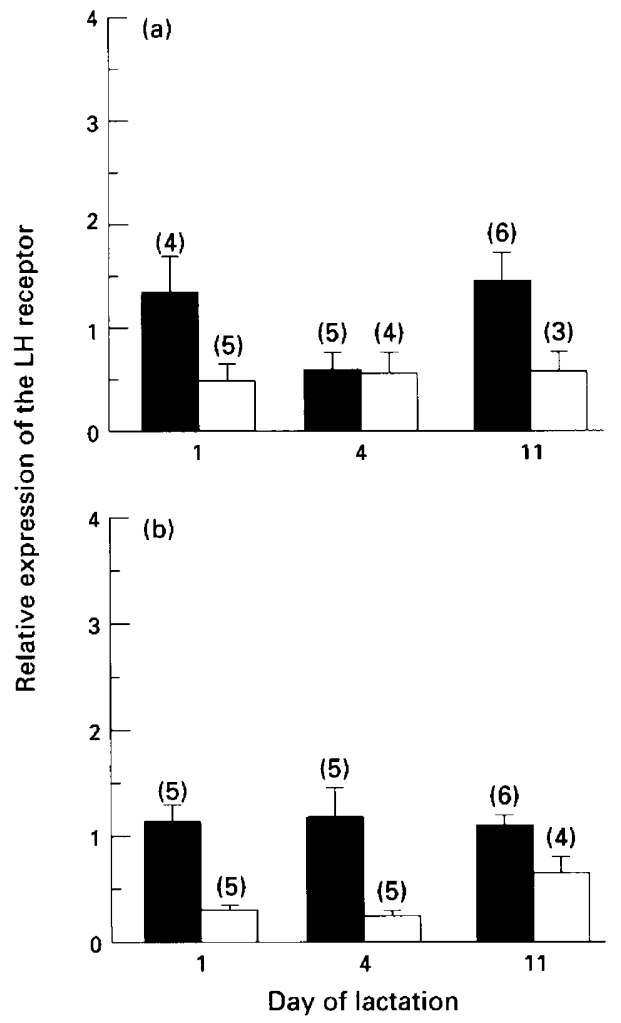

Fig. 3. The concentration of mRNA encoding the $\mathrm{LH}$ receptor in the rabbit ovary at different stages of lactation. The amount of mRNA encoding the receptor was quantified on slot blots and expressed in arbitrary units relative to the intensity of the $\beta$-actin signal for each rabbit at each stage of lactation. The amount of hybridization was considered significant above a threshold of 0 , which was the hybridization intensity of spleen RNA $/$ actin (negative control). Mean values ( \pm SEM) were calculated for each category to facilitate visualization of the results, and the number per group is indicated in parentheses.

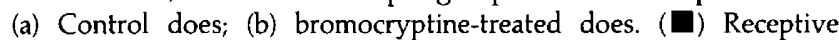
females; ( $\square$ ), nonreceptive females. Receptive does have a significantly higher mean amount of LH receptor mRNA than do nonreceptive rabbits $(P<0.001)$.

diminished by bromocryptine, indicating that prolactin deprivation can relieve some negative control exerted on $\mathrm{LH}$ receptor mRNA translation or stability of the protein. Nevertheless, it appears that prolactin may exert an antifertility effect at the ovarian level, by inhibiting the number of $\mathrm{LH}$ receptors expressed.

The concentration of prolactin fluctuates according to the stage of lactation (Durand and Djiane, 1977) and could influence prolactin receptor expression as seen at the mRNA or at the receptor level. The increase in the concentration of prolactin receptor mRNA observed in bromocryptine-treated animals is highly correlated with an increase in the number of prolactin receptors. The increase in prolactin binding sites could be due to increased transcription and translation, or to a decrease in the proportion of receptors occupied by endogenous hormone, resulting in an increase of free receptors. Receptive behaviour is only moderately correlated with the number of prolactin receptors, but not with the concentration of mRNA.

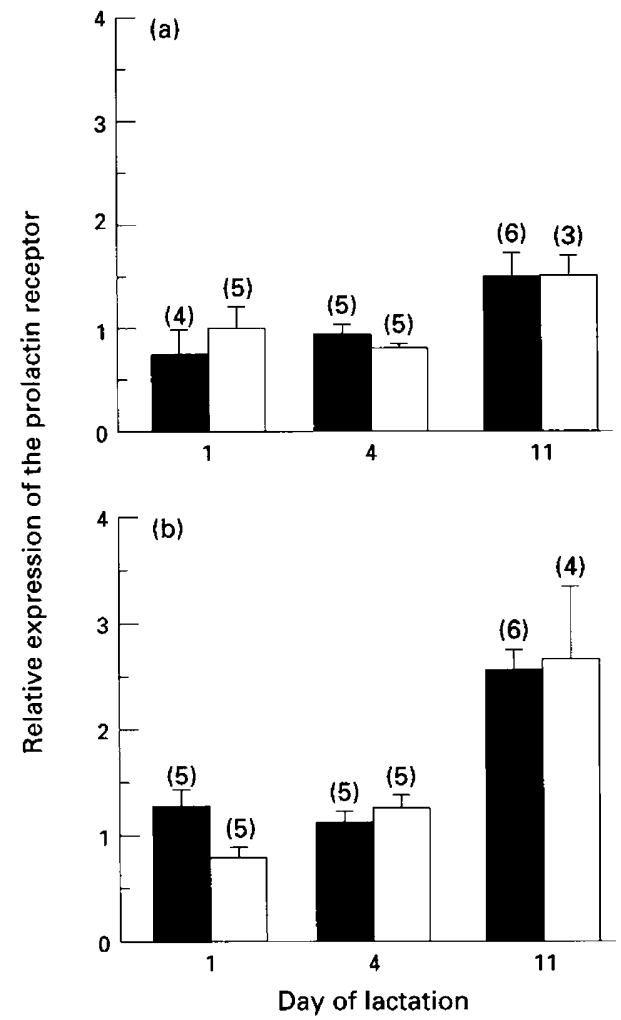

Fig. 4. Prolactin receptor mRNA concentrations in the rabbit ovary at different stages of lactation. The amount of mRNA encoding the prolactin receptor was quantified on slot blots and expressed in arbitrary units relative to the intensity of the $\beta$-actin signal. The amount of hybridization was considered significant above a threshold of 0 , which was the hybridization intensity of spleen RNA/actin (negative control). Mean values ( \pm SEM) were calculated for each category to facilitate visualization of the results, and the number per group is indicated in parentheses. (a) Control does; (b) bromocryptinetreated does. ( $\square$ ) Receptive females; $(\square)$, non-receptive females. Bromocryptine treatment significantly increases the amount of prolactin receptor mRNA $(P<0.001)$, particularly on day 11 of lactation $(P<0.05)$.

Bromocryptine treatment leads to an increase in the number of prolactin receptors. Prolactin amplifies its receptor concentration in the rat liver (Manni et al., 1978) and rabbit mammary gland. However, prolactin also increases endocytosis and degradation of its own receptor in $\mathrm{CHO}$ cells transfected with the rabbit prolactin receptor (Genty et al., 1994). This sharp suppression of prolactin secretion by bromocryptine treatment may remove the negative short-term control exerted by prolactin receptors.

In many species, the high concentrations of prolactin required for lactation and induced by suckling have been associated with a reduction in normal gonadotrophin secretion, especially with the pulsatile secretion of $\mathrm{LH}$, which disrupts normal ovarian function. Similar results have been observed in seasonal infertility in ungulates and in pathological hyperprolactinaemia in humans (McNeilly, 1980). However, a specific role for prolactin in the suppression of gonadotrophin secretion has often been suggested in animals displaying anoestrous behaviour during lactation. An analysis of GnRH- and 


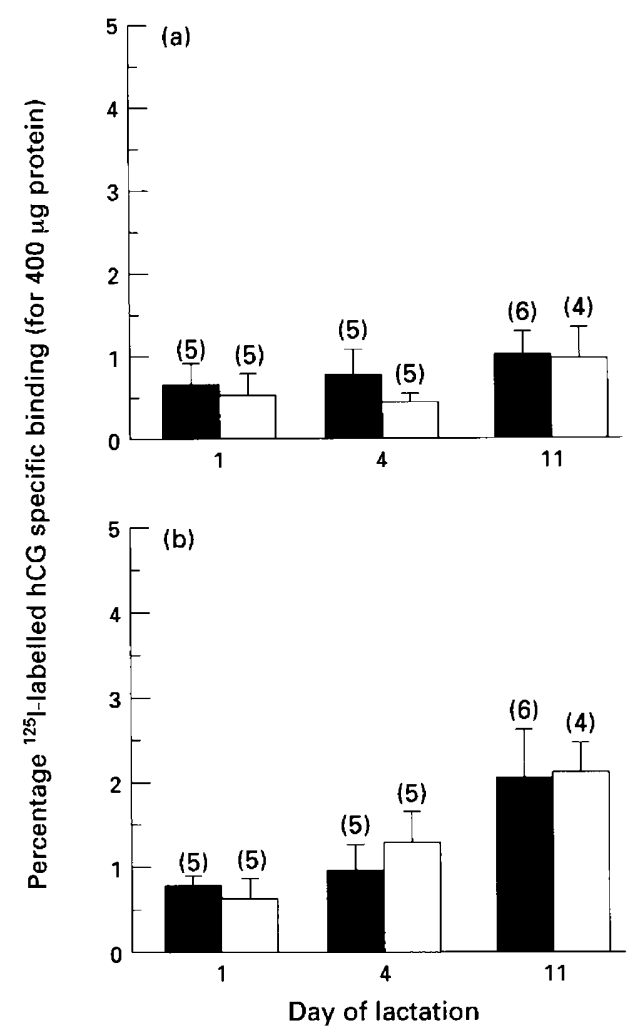

Fig. 5. Evaluation of LH binding sites in the rabbit ovary at different stages of lactation. $\left.{ }^{125} \mathrm{I}\right]$-labelled hCG was used as a tracer. Specific binding $(400 \mu \mathrm{g}$ of protein for $\mathrm{LH}$ receptor determinations) was expressed as a percentage of the total radioactivity added to the tube, and was determined for each rabbit at each stage of lactation. Mean values ( \pm SEM) were calculated for each category to facilitate visualization of the results, and the number per group is indicated in parentheses. (a) Control does; (b) bromocryptine-treated does. (ם) Receptive females; ( $\square$ ) nonreceptive females. The number of LH receptors is the same on days 1 and 4 of lactation but increases on day $11(P<0.05)$. Bromocryptine treatment significantly increased LH receptor content $(P<0.01)$.

prolactin-specific binding sites in receptive and nonreceptive does in the pituitary gland and hypothalamus should help to delineate a direct interaction if it exists.

The antagonism between $\mathrm{LH}$ and prolactin regarding fertility has been amply documented at the hormonal level in some species; however, little is known in the rabbit. According to the present experiments, it also seems to be exerted at the level of the ovary. The mechanism remains to be elucidated, but some practical conclusions can be drawn. Receptivity is correlated with an increase in the number of follicles and consequently with the concentration of LH receptor mRNA and prolactin receptors in rabbits. Suppression of prolactin secretion enhances the number of $\mathrm{LH}$ receptors (Genty et al., 1987), as if the translation of the LH-receptor mRNA is in some way controlled by prolactin.

In conclusion, the control of expression of prolactin receptors is mainly exerted at the mRNA level during lactation, while that of $\mathrm{LH}$ receptors occurs at the level of the protein. These results indicate differences in the mechanisms controlling the expression of the two receptors. The prolactin receptor

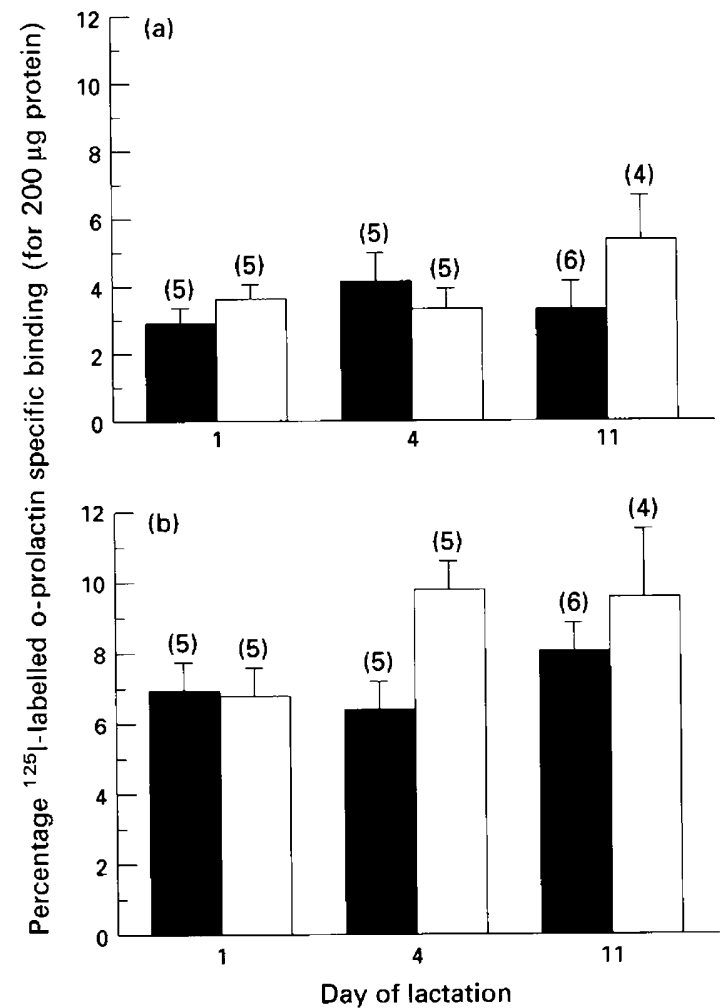

Fig. 6. Evaluation of prolactin binding sites in the rabbit ovary at different stages of lactation. ${ }^{125} \mathrm{I}$-labelled o-prolactin was used as a tracer. Specific binding ( $200 \mu \mathrm{g}$ of protein for prolactin receptor determinations) was expressed as a percentage of the total radioactivity added to the tube, and was determined for each rabbit at each stage of lactation. Mean values ( \pm SEM) were calculated for each category to facilitate visualization of the results, and the number per group is indicated in parentheses. (a) Control does; (b) bromocryptinetreated does. ( $\square$ ) Receptive females; ( $\square$ ) nonreceptive females. Bromocryptine treatment significantly increased prolactin receptor content $(P<0.001)$.

mRNA seems to display a longer half-life (approximately $40 \mathrm{~h}$; Djiane ef al., 1982) than does the LH receptor mRNA (approximately $60 \mathrm{~min}$; Lu et al., 1993). The prolactin receptor has a short half-life at the cell surface, where it is subjected to hormone-dependent endocytosis and degradation (Djiane $e$ t al., 1982; Genty et al., 1994). This partly explains why inhibiting prolactin secretion enhances the number of prolactin receptors in the ovary. On the contrary, downregulation of $\mathrm{LH}$ receptors does not occur at physiological concentrations (Genty et al., 1987) and the lifespan of the receptor is $>32 \mathrm{~h}$ (B. Goxe and $R$. Salesse, unpublished), as has been demonstrated for the receptor for the related thyroid-stimulating hormone (Ban et al., 1992).

This study provides a better understanding of the physiological mechanisms controlling the restoration of ovarian activity after parturition, and may be of help in developing appropriate treatments for animals undergoing a delay in oestrus.

The authors are grateful to P. Durand, J. J. Remy and H. Jammes for critically reading the manuscript, as well as for helpful advice during 
the course of this work. They thank $C$. Chabanet for her help with the statistical analysis of the data, and L. Fortun, D. Guémene and M. Mills for their assistance with the rabbit prolactin dosages. They are indebted to A. F. Parlow for the gift of immunoreagents (rabbit prolactin radioimmunoassay) and to $\mathrm{R}$. Canfield at the Center of Population Research (NIH, Bethesda, MD) for the gift of hCG. This study was supported by grants from the Institut National de la Recherche Agronomique, France.

\section{References}

Alonso S, Minty A, Bourlet $Y$ and Buckingham M (1986) Comparison of three actin-coding sequences in the mouse; evolutionary relations between the actin genes of warm-blooded vertebrates Journal of Molecular Evolution 23 $11-22$

Ban T, Kosugi S and Kohn L (1992) Specific antibody to the thyrotropin receptor identifies multiple receptor forms in membranes of ceils transfected with wild-type receptor complementary deoxyribonucleic acid: characterization of their relevance to receptor synthesis, processing, structure, and function Endocrinology $131815-829$

Beyer C and McDonald P (1973) Hormonal control of sexual behavior in the female rabbit Advances in Reproductive Physiology 6 185-219

Beyer C and Rivaud N (1969) Sexual behavior in pregnant and lactating domestic rabbits Physiology and Behavior 4 753-757

Channing CP and Evans VW (1982) Stimulatory effect of ovine prolactin upon porcine granulosa cell secretion of inhibitory activity of oocyte maturation Endocrinology 111 1746-1748

Chomczynski P and Sacchi N (1987) Single-step method of RNA isolation by acid guanidinium thiocyanate-phenol-chloroform extraction Analytical Biology 162 156-159

Crighton DB and Lamming GE (1969) The lactational anoestrus of the sow: the status of the anterior pituitary-ovarian system during lactation and after weaning Joumal of Endocrinology 43 507-519

Djiane J, Durand P and Kelly PA (1977) Evolution of prolactin receptors in rabbit mammary gland during pregnancy and lactation Endocrinology 100 1348-1356

Djiane J, Delouis C and Kelly PA (1982) Prolactin receptor turnover in explants of pseudopregnant rabbit mammary gland Molecular and Cellular Endocrinology 25 163-170

Durand $P$ and Djiane $J$ (1977) Lactogenic activity in the serum of rabbits during pregnancy and early lactation Journal of Endocrinology 75 33-42

Dusanter-Fourt I, Gaye P, Belair L, Petridou B, Kelly PA and Djiane J (1991) Prolactin receptor gene expression in the rabbit: identification, characterization and tissue distribution of several prolactin receptor messenger RNAs encoding a unique precursor Molecular and Cellular Endocrinology 77 181-192

Edery M, Jolicoeur C, Levi-Meyrueis C, Dusanter-Fourt I, Petridou B, Boutin JM, Lesueur L, Kelly PA and Djiane J (1989) Identification and sequence analysis of a second form of prolactin receptor by molecular cloning of complementary DNA from rabbit mammary gland Proceedings National Academy of Sciences USA 86 2112-2116

Erickson GF (1983) Primary cultures of ovarian cells in serum-free medium as models of hormone-dependent differentiation Molecular and Cellular Endocrinology $2921-49$

Genty N, Salesse R and Garnier J (1987) Internalization and recycling of lutropin receptors upon stimulation by porcine lutropin and human choriogonadotropin in porcine Leydig cells Biology of the Cell 59 129-136

Genty N, Paly J, Edery M, Kelly PA, Djiane J and Salesse R (1994) Endocytosis and degradation of prolactin and its receptor in Chinese hamster ovary cells stably transfected with prolactin receptor cDNA Molecular and Cellular Endocrinology 99 221-228

Goxe B, Salesse R, Remy JJ, Genty N and Garnier J (1992) LH receptor RNA and protein levels after hormonal treatment of porcine granulosa cells in primary culture Journal of Molecular Endocrinology 8 119-129

Greenwood F, Hunter W and Glover J (1963) The preparation of iodine 131 labelled human growth hormone of high specific radioactivity Biochemical Journal 89 114-123
Hamada Y, Schlaff S, Kobayashi Y, Santulli R, Wright K and Wallach E (1980) Inhibitory effect of prolactin on ovulation in the in vitro perfused rabbit ovary Nature 285 161-163

Howie PW and McNeilly AS (1982) Effect of breast-feeding patterns on human birth intervals Joumal of Reproduction and Fertility 65 545-557

Jahn GA, Edery M, Belair L, Kelly PA and Djiane J (1991) Prolactin receptor gene expression in rat mammary gland and liver during pregnancy and lactation Endocrinology 128 2976-2984

Kelly PA, Diiane J, Postel-Vinay MC and Edery M (1991) The prolactin/growth hormone receptor family Endocrine Reviews 12 235-25I

Lamb IC, Partridge GG, Fuller MF and Racey PA (1988) Fertility of the early post partum, lactating domestic rabbit Theriogenology $3075-82$

Loosfelt H, Misrahi M, Atger M, Salesse R, Vu Hai MT, Jolivet A, GuiochonMantel A, Sar S, Jallal B, Garnier J and Milgrom E (1989) Cloning and sequencing of porcine $\mathrm{LH}-\mathrm{hCG}$ receptor $\mathrm{CDNA}$; variants lacking transmembrane domain Science 245 525-528

Lowry OH, Rosebrough J, Lewis M, Farr A and Randall RJ (1951) Protein measurement with the folin phenol reagent Journal of Biological Chemistry $193265-276$

Lu D, Peegel H, Mosier S and Menon KM) (1993) Loss of lutropin/human choriogonadotropin receptor messenger ribonucleic acid during ligandinduced down-regulation occurs post-transcriptionally Endocrinology 132 235-240

McNatty KP, Sawers RS and McNeilly AS (1974) A possible role for prolactin in control of steroid secretion by the human Graafian follicle Nature $\mathbf{2 5 0}$ 653-655

McNeilly AS (1980) Prolactin and the control of gonadotrophin secretion in the female Joumal of Reproduction and Fertility 58 537-549

McNeilly AS (1987) Prolactin and the control of gonadotrophin secretion Joumal of Endocrinology 115 1-5

Magoffin DA and Erickson GF (1982) Prolactin inhibition of luteinizing hormone-stimulated androgen synthesis in ovarian interstitial cells cultured in defined medium: mechanism of action Endocrinology 111 2001-2007

Manni A, Chambers MJ and Pearson OH (1978) Prolactin induces its own receptors in rat liver Endocrinology 103 2168-2171

Moret B (1980) Comportement d'estrus chez la lapine Cuniculture 33 159-161

Muccioli G, Lando D, Bellussi G and Di Carlo R (1983) Physiological and pharmacological variations in rabbit prolactin plasma levels Life Sciences 32 703-710

Nicoll CS (1980) Ontogeny and evolution of prolactin's functions Federation Proceedings $392563-2565$

Peters AR and Lamming GE (1990) Lactational anoestrus in farm animals Oxford Reviews of Reproductive Biology, pp 245-288 Ed SR Milligan. Clarendon Press, London

Puissant C and Houdebine LM (1990) An improvement of the single-step method of RNA isolation by acid guanidinium thiocyanate-phenolchloroform extraction BioTechniques 8 148-149

Richards JS and Williams JJ (1976) Luteal cell receptor content for prolactin (PRL) and luteinizing hormone (LH): regulation by LH and PRL Endocrinology 99 1571-1581

Stoufflet I and Caillol M (1988) Relation between circulating sex steroid concentrations and sexual behaviour during pregnancy and post partum in the domestic rabbit Journal of Reproduction and Fertility 82 209-218

Theau-Clément $\mathbf{M}$ and Roustan A (1992) A study on relationships between receptivity and lactation in the doe, and their influence on reproductive performances. In Proceedings of Vth Congress of World Rabbit Science, July 25-30 1992, Corvallis, USA (Vol. A), pp 412-421 PR Cheeke Ed.

Tsai-Morris C-H, Ghosh M, Hirshfield AN, Wise PM and Brodie AMH (1983) Inhibition of ovarian aromatase activity by PRL in vivo Biology of Reproduction 29 342-346

Veldhuis JD and Hammond JM (1980) Oestrogens regulate divergent effects of prolactin in the ovary Nature 284 262-263

Wang C, Hseush AJW and Erickson GF (1980) Prolactin inhibition of estrogen production by cultured rat granulosa cells Molecular and Cellular Endocrinology 20 135-144

Yoshimura Y, Nakamura Y, Oda T, Ando M, Ubukata Y, Koyama N, Karube M and Yamada H (1992) Effects of prolactin on ovarian plasmin generation in the process of ovulation Biology of Reproduction 46 322 -327 